\title{
Grape Infusions: The Flavor of Grapes and Health-Promoting Compounds in Your Tea Cup
}

\author{
Alice Vilela ${ }^{1, *(1)}$ and Teresa Pinto ${ }^{2} \mathbb{C}$ \\ 1 CQ-VR, Department of Biology and Environment, School of Life Sciences and Environment, Enology \\ Building, Chemistry Research Centre, University of Trás-os-Montes and Alto Douro (UTAD), \\ 5000-801 Vila Real, Portugal \\ 2 CITAB, Department of Biology and Environment, School of Life Sciences and Environment, Centre for the \\ Research and Technology of Agro-Environmental and Biological Sciences, University of Trás-os-Montes and \\ Alto Douro, 5000-801 Vila Real, Portugal \\ * Correspondence: avimoura@utad.pt
}

Received: 8 May 2019; Accepted: 4 July 2019; Published: 1 August 2019

check for updates

\begin{abstract}
Traditionally, tea, a beverage made from the processed leaves of the tea plant, Camellia sinensis, and herbal infusions have been primarily consumed for their pleasant taste. Nowadays, they are also consumed because they contain nutraceutical compounds, such as polyphenols. Grapes and grape/wine sub-products such as non-fermented/semi-fermented or fermented grapes, skins, and seeds are a rich source of health-promoting compounds, presenting a great potential for the development of new beverages. Therefore, these grape/wine sub-products are used in the beverage sector for the preparation of infusions, tisanes, and decoctions. Besides polyphenols, fermented grapes, skins, and seeds, usually discarded as waste, are enriched with other health-promoting/nutraceutical compounds, such as melatonin, glutathione, and trehalose, among others, which are produced by yeasts during alcoholic fermentation. In this review, we summarize the benefits of drinking herbal infusions and discuss the potential application of some grapevine fermentation waste products in the production of healthy beverages that we can call grape infusions.
\end{abstract}

Keywords: infusions; tea; tisanes; grape sub-products valorization; nutraceutical properties; human health

\section{Introduction}

\subsection{Plant Infusions}

Plant infusions, commonly called teas or tisanes, are the most popular form of herbal medicine in the world, used for thousands of years. The habit of consuming teas and herbal infusions is increasingly embedded in the routine of Americans and Europeans [1] due to their potential health benefits, attractive flavor and taste, and relatively low retail price [2].

However, most people do not know how to distinguish tea from infusions, tisanes, and decoctions. An infusion is produced by pouring boiling water over a certain amount of the plant of interest (roots, flowers, leaves, seeds, twigs, or other), letting it rest for a few minutes, and then straining it [3]. The resulting liquid is called infusion. The term "decoction" designates a plant infusion obtained by a different method, using, especially, its fibrous parts, such as stems, roots, barks, seeds, rhizomes, and woods. The method consists in immersing a part of the plant in cold water and heating up to boiling, which is maintained for 3 to $10 \mathrm{~min}$. During the cooling period, the container should remain covered [4]. An infusion prepared from two or more different plants is named a "tisane" [5]. The term "tea" should be used exclusively to designate infusions obtained from the leaves of Camellia sinensis, a member of 
the Theaceae family; however, this denomination is commonly used to describe an infusion prepared from any plant.

\subsection{Tea and Other Herbal Infusions}

White, green, oolong, and black teas are different types of tea made from the leaves of the same species, C. sinensis, which undergo different post-harvest treatments which modify their color and the resulting aroma, flavor, and number of polyphenols present (Figure 1).

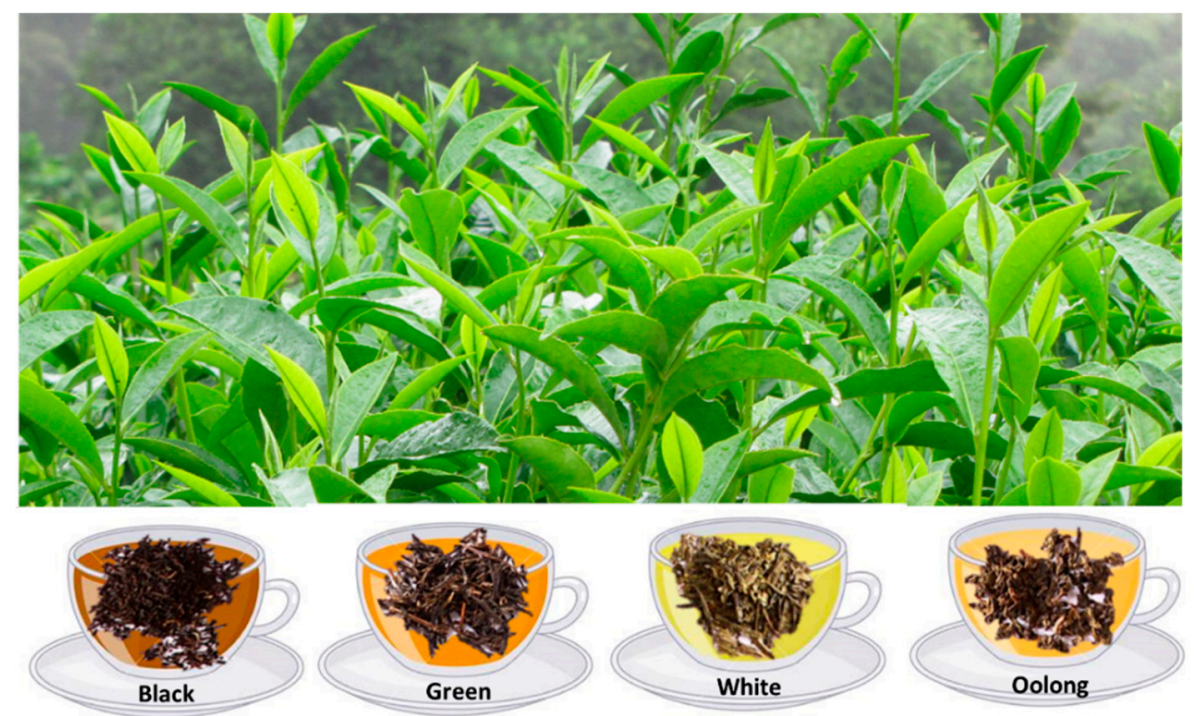

Figure 1. The Camellia sinensis plant and the different types of tea that can be produced from its leaves. Photo adapted from Forest \& Kim Starr-Jardim Botânico UTAD, 2019 [6].

White tea, made from new growth buds and young leaves, is the least processed of all teas and, as a result, it has the most delicate flavor and aroma. The leaves are not rolled or crushed during processing but are plucked and dried in the sun and shade. This type of tea can be semi-fermented or non-fermented and releases the least amount of caffeine among all teas [7]. Sweet or flowery flavors are characteristic of this type of tea. The name "white tea" is due to the fact that it is made from unfolded tea buds with white trichomes which give a silvery appearance. It is one of the most expensive teas for the consumer [6]. White tea is consumed essentially by people concerned about their health since, because of its characteristics, it is considered to have a high therapeutic value [8].

Green tea is a less fermented tea and contains the highest quantity of tea catechins. To produce this type of tea, the leaves are steamed or pan-roasted to inactivate their enzymes and then are dried; drying preserves their constituents [7]. The main chemical constituents of dried green-tea leaves are polyphenols (37\%), carbohydrates (25\%), caffeine (15\%), and amino acids $(6.5 \%)$ [9]. Green tea has a fresh, grassy flavor, being more astringent and subtler than oolong or black tea [10].

Oolong tea is semi-fermented and also known as a hybrid of black and green tea. With characteristics of both black and green tea, sweet, fruity, and flower-like odors, this type of tea is the most preferred in China. Originally produced with C. sinensis var. sinensis in Fujian Province in southeast China, it is nowadays also cultured in other regions of China together with other subspecies such as $C$. sinensis var. assamica [11].

Black tea is a totally fermented tea. Fermentation is an extremely important process for the development of tea aroma and flavor, which change progressively as the process develops. In fact, the scent of black tea depends on the formation of volatile substances consisting of essential oils and other molecules like amino acids [12]. Biochemically, the so-called "fermentation" process is, in fact, an oxidation which involves enzymatic reactions: after rupture, the tea leaves expose the cell sap (juice that is simply the cytoplasmatic content), whose chemical constituents and enzymes react in 
the presence of atmospheric oxygen $[13,14]$. The enzymes polyphenol oxidase and peroxidase act on catechins in the presence of oxygen and form oxidized polyphenolic compounds such as theaflavins and thearubigins [15]. The leaves' cells are ruptured by rolling the leaves. According to Carloni and coworkers [16], this can be done by two distinct methodologies: using the "crush-tear-curl" process, which allows obtaining small particles suitable for tea bags, or using rolls, which provide large-leaf tea. Black teas are distinct for their honey and flower-like flavor [10].

Infusions can be prepared from a great diversity of edible, aromatic, and medicinal plants, besides C. sinensis. The beverages obtained, since antiquity, are very pleasant due to their attractive flavor, taste, and biological and physiological functions, which are beneficial for human health $[17,18]$. Currently, the demand and use of plants to obtain infusions with medicinal purposes are increasing, and a great variety of these herbal products are available on the market. Many are obtained from plants that are familiar to the consumers. Table 1 shows some examples of aromatic and medicinal plants commonly used for the preparation of infusions, as well as their main benefits.

Table 1. Botanical names, families, medicinally used parts, and health benefits of various aromatic and medicinal plants. Adapted from Herrera et al. [19].

\begin{tabular}{|c|c|c|c|c|}
\hline Health Benefits & Herbal Infusions & Scientific Name & Family & Tissues Used for Infusion \\
\hline \multirow{4}{*}{ Nervous System } & Linden & Tilia platyphyllos Scop. & Malvaceae & Inflorescences \\
\hline & Passion flower. & Passiflora incarnata $\mathrm{L}$. & Passifloraceae & Leaves and flowers \\
\hline & St. John's Wort & Hypericum perforatum $\mathrm{L}$. & Clusiaceae & Flowers \\
\hline & Valerian & Valeriana officinalis L. & Caprifoliaceae & Roots, rhizomes, and stolons \\
\hline \multirow{6}{*}{ Digestive System } & Boldo & Peumus boldus molina & Monimiaceae & Leaves and cortex \\
\hline & Chamomile & Matricaria chamomilla $\mathrm{L}$. & Asteraceae & Flower heads \\
\hline & Fennel & Foeniculum vulgare M. & Apiaceae & Fruits, seeds, root, leaves \\
\hline & Green Fruits & Pimpinella Anisum L. & Apiaceae & Fruits \\
\hline & Pennyroyal & Mentha pulegium L. & Lamiaceae & Leaves \\
\hline & Senna & Cassia Angustifolia Vahl & Fabaceae & Leaves and fruits \\
\hline \multirow{6}{*}{$\begin{array}{c}\text { Cardiovascular } \\
\text { System }\end{array}$} & Lemon verbena & Aloysia citrodora $\mathrm{P}$. & Verbenaceae & Leaves \\
\hline & Hawthorn & Crataegus oxyacanthal & Rosaceae & Floral tops, leaves, fruits, and cortex \\
\hline & Horsetail & Equisetum arvense L. & Equisetaceae & Stem \\
\hline & Olive Tree & Olea europaea L. & Oleaceae & Leaves and fruits \\
\hline & Rosemary & Rosmarinus officinalis L. & Lamiaceae & Leaves, stems, and flowers \\
\hline & Thyme & Thymus vulgaris $\mathrm{L}$. & Lamiaceae & Leaves and flowers \\
\hline
\end{tabular}

\subsection{Infusions and Health}

There are several reasons why more and more consumers are drinking tea and infusions. Tea and infusions started to be consumed because of their taste and aroma, and their use gradually became rooted in the culture of several countries [20]. Nowadays, they are drunk also for their health benefits due to the chemical components of the tea leaves [21,22]. Several studies have already shown the close relationship between the consumption of foods rich in antioxidants and the incidence of certain diseases [23].

Catechins (Figure 2) are the major components of green tea leaves [24]. 


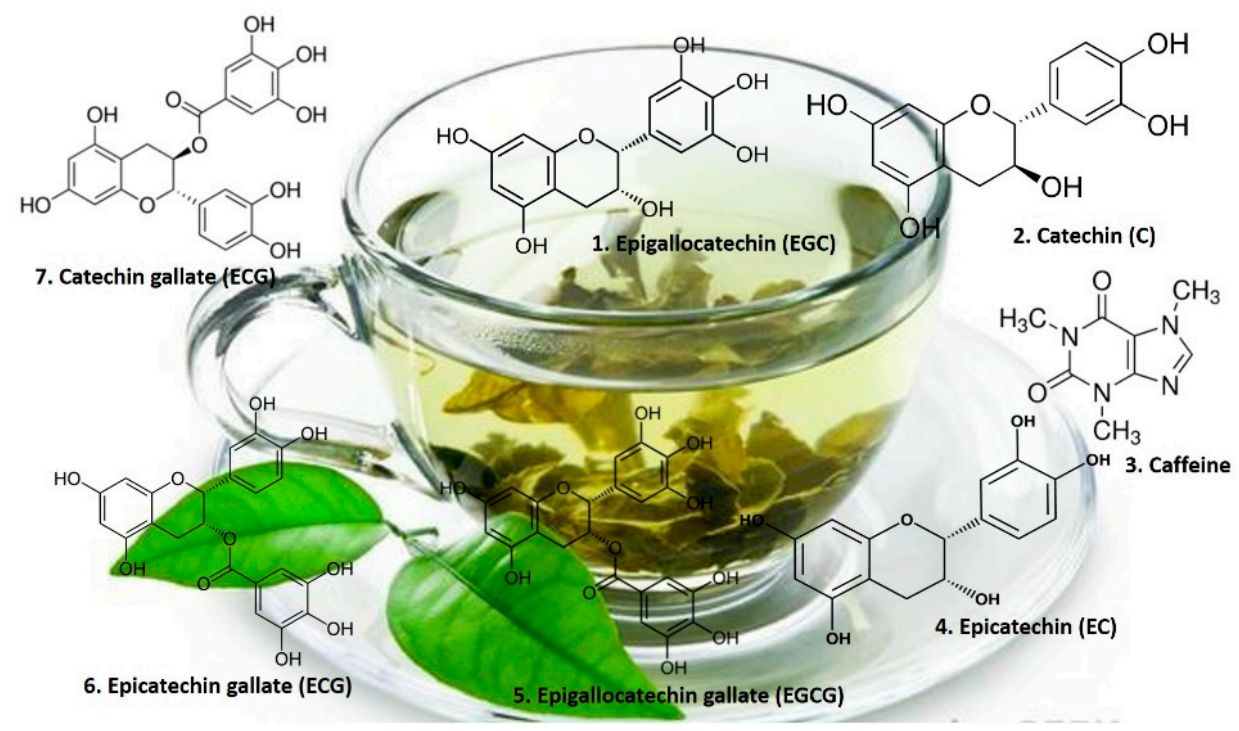

Figure 2. Chemical structures of catechins present in green tea.

In black tea, catechins are oxidized and dimerized during fermentation to yellow-orange "pigments" called theaflavins or polymerized to red "pigments" called thearubigins. Oolong tea contains a mixture of catechins, theaflavins, and thearubigins [24]. Therefore, polyphenols, in particular the flavonoid theaflavins, theaflavic acids, and bis flavanols, are considered the main chemical black tea compounds with powerful antioxidant properties (Figure 3) [25].

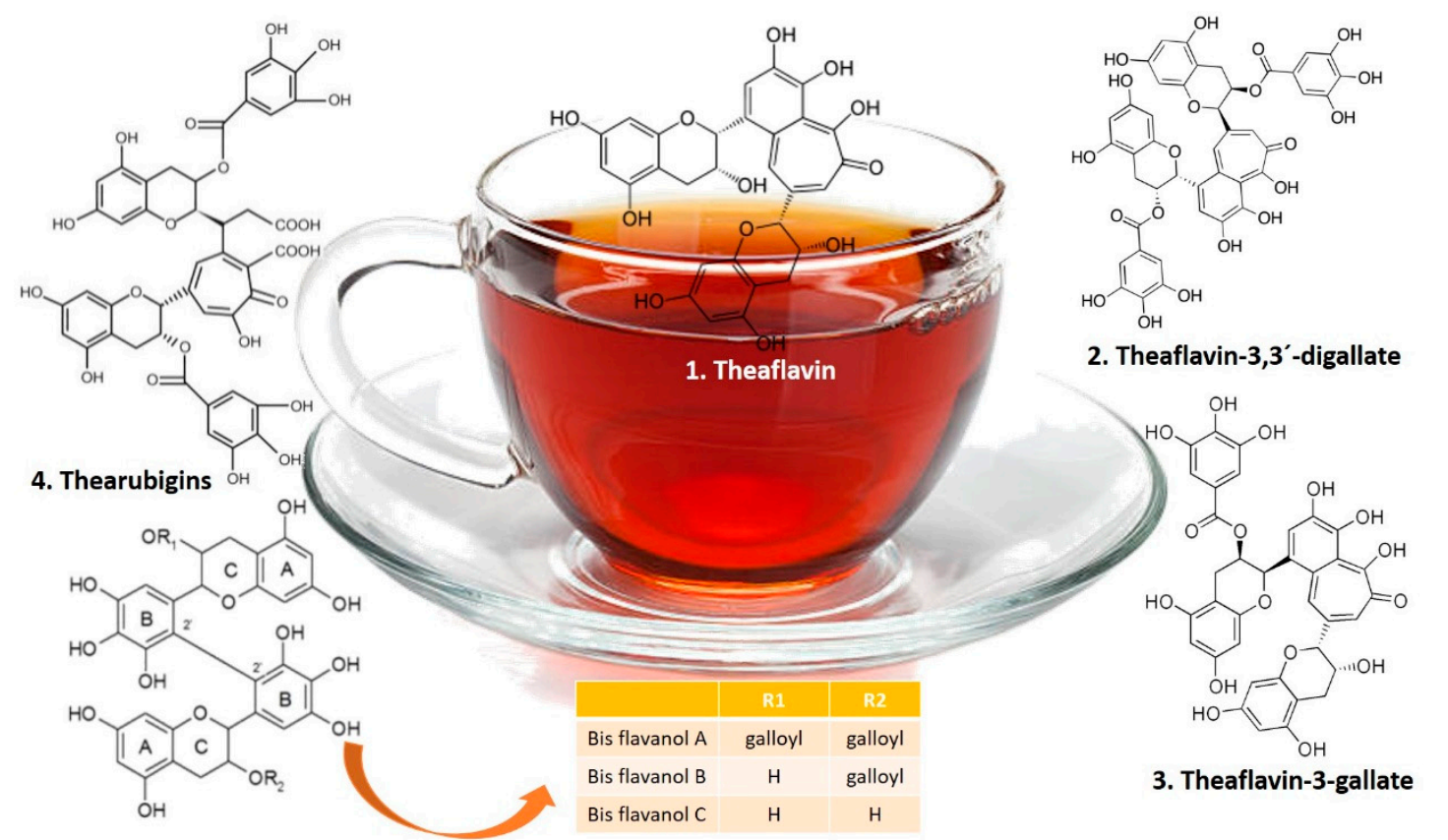

Figure 3. Chemical structures of theaflavins, thearubigins, and bis flavanols in black tea.

The antioxidant activity of phenolic compounds is mainly due to their redox properties, which allow them to act as free radical scavengers which remove endogenously generated superoxide, peroxyl, and hydroxyl radicals [7]. In addition, they have a metal-chelating potential [26].

Leung and co-workers [24] demonstrated that the antioxidant potential activity of theaflavins and catechins in tea varies according to the following order: theaflavin-3,3'-digallate $>(-)$-epicatechin gallate $\geq(-)$-epigallocatechin gallate $\geq$ theaflavin- $3^{\prime}$-gallate $\geq$ theaflavin-3-gallate $>$ theaflavin $\geq$ 
(-)-epicatechin $>(-)$-epicatechin gallate, established by using human low-density lipoprotein (LDL) cholesterol as the oxidation model. When they compared their work with a former study by Yoshino and collaborators [27] (who showed, in rat liver homogenates, that both green and black tea infusions had similar antioxidant activities), they concluded that the theaflavins present in black tea have similar antioxidant potency as the catechins present in green tea.

Being rich in natural antioxidants, tea and herbal infusions are considered to have anti-microbial and anti-cancerous properties [7]. These beverages also offer beneficial effects against kidney stones [28] and dental caries [29], maintain bone mineral density [30], and can be used to treat malaria, high blood pressure [31], cough, stomach pain, fever [32], and diarrhea [33], besides acting as tranquilizers [34]. However, Massey [35] reports that tea consumption may increase the formation of calcium oxalate stones and advise those prone to calcium oxalate stone formation to restrict tea consumption.

\subsection{Nutraceutical Value of Food and Beverages}

Although the term Nutraceutical (from 'Nutrition' and 'Pharmaceutical') was suggested in the late 1980s by Stephen De Felice, Founder and Chairman of the Foundation for Innovation in Medicine [36], it is in Ancient Greece that the idea of the beneficial relationship between food and health first appeared, as shown by the words of Hippocrates (460-377 BC): Let food be your medicine and medicine your food [37]. In fact, the concept of nutraceuticals is not new, and functional foods are part of a new food concept, launched in Japan in the 1980s through a government program that aimed to develop healthy foods for the aging population that had a long-life expectancy [38]. Since then, this concept has evolved considerably. The term nutraceutical was initially defined as a food or part of a food that has medical or health benefits, including disease prevention and treatment; however, nowadays, the term nutraceutical lacks an accurate definition, although nutraceuticals represent a growing area of the biomedical research [39]. According to Santini and coworkers [40] and Daliu [36], this is due to the absence of a clear categorization of products such as food supplements, phytotherapeutics, pre- and probiotics, functional foods, and fortified foods. Despite the wide range of definitions for this term, there are two essential requirements for a particular food to be a nutraceutical: to contribute to the prevention and/or treatment of a particular disease (physiological benefits) and to reduce the onset of chronic diseases [41,42]. Considering the definition of nutraceuticals by Dudeja and Gupta, reported above [42], products such as dietary supplements, genetically engineered "designer" foods, herbal products such as herbal infusions and tea, processed foods [42], dietary fibers, polyunsaturated fatty acids, proteins, peptides, amino acids, minerals, antioxidant vitamins, and other antioxidants [43] are included in the designation of nutraceuticals.

The growth of the nutraceutical sector is encouraged by the interest in improving physical and mental well-being and health and in the ability to regulate bodily functions in order to help protect against diseases such as hypertension, diabetes, cancer, osteoporosis, and coronary diseases [44] and to compensate for an incorrect lifestyle [44,45]. It is estimated that nutraceuticals products are used in $50-70 \%$ of the developed countries and women use more nutraceuticals than men [46].

As a result of interdisciplinary research and collaboration between academic researchers and industry, new products with nutritional potential, safety, and therapeutic effects appear daily in the market. Tea and other herbal infusions are the nutraceuticals products more consumed in all world and their health therapeutic benefits are well known. However, the demonstration of the beneficial properties and reduced secondary effects of nutraceuticals, including tea and other herbal infusions, still needs more support from scientific studies.

\section{Grapes and Vine Leaves Composition, Anatomy, and Histology}

The grapevine (Vitis spp.) is a climbing plant considered one of the oldest in the world, having been found in fossils that preceded the existence of Homo sapiens [47]. Indeed, the grapevine is one of the most important fruit crops in the world. For centuries, the therapeutic benefits of grapes and other byproducts from the vineyards have been empirically used for medical purposes such 
as the treatment of bleeding, pain, inflammation, nausea, diarrhea, gastroenteritis, or skin diseases. Nowadays, consumers are increasingly demanding products with high nutritional quality that are beneficial to health. Thus, studies have been conducted on several foods with the aim of satisfying the population's demand. Grapes and vine leaves are considered a rich source of phenolic compounds and have a tremendous potential for the development of new foods and beverages. Indeed, in addition to grape or wine, studies have shown that vine byproducts, such us jam, grape juice, jelly, molasses, raisins, and leaves, also have therapeutic properties [48]. In some European countries, Vitis vinifera leaves have traditionally been used as food $[49,50]$, while in others they are considered a waste and thus discarded, rather than valorized [51].

A study comparing 10 grape cultivars grown in southern Georgia, USA, showed that the concentration of phenolic compounds (phenols, anthocyanins, and flavonols) is different in the various plant structures constituting leaf and berry, being higher in the seed $(2178.8 \mathrm{mg} / \mathrm{g}$ gallic acid equivalents), followed by the skin $(374.6 \mathrm{mg} / \mathrm{g})$, and finally the leaf $(351.6 \mathrm{mg} / \mathrm{g})$ [52]. Flavonoids and proanthocyanidins (procyanidins and prodelphinidins) are mostly found in the seeds and skin of grapes. Grape seed proanthocyanidins comprise only (+)-catechin, (-)-epicatechin, and procyanidins [53], whereas grape skin proanthocyanidins comprise both prodelphinidins and procyanidins. The prodelphinidins monomers are $[(+)$-catechin, $(-)$-epicatechin, $(+)$-gallocatechin, and $(-)$-epigallocatechin] units and were only found in grape skin [54]. However, other compounds such as sugars (glucose, fructose, and sucrose), organic acids (malic, tartaric, and citric acid), and aroma precursors (volatiles and non-volatiles) are present at different concentrations in the grape berry tissue layers [55].

Besides the berry, also the leaf is an important source of phenolic compounds, although their concentrations depend on the vegetative development of the leaf, with a higher total phenol concentration in September (3339 mg GAE/L) than in May (2911 mg GAE/L) [56]. The gallic acid is a dominant phenolic acid in the vine leaf, but other constituents contribute to the beneficial properties of its extract [57], proving that grape leaves are an optimal material for the manufacture of new foods and beverages. Indeed, flavanols [58], caftaric acid [59], hydroxycinnamoyl tartaric esters, catechin, quercetin, rutin, and kaempferol [48] are other compounds that can be found in vine leaves. According to Sat and coworkers [60], significant amounts of vitamins, minerals, and crude fiber can also be found in the leaves of various $V$. vinifera varieties. In Figure 4, the ultrastructure of both grape berries and leaves of $V$. vinifera can be observed. The vine fruit is a berry with a rounded shape, stratified in three different tissue layers: (a) the skin or outer exocarp (6-8-cell layer), a heterogeneous region constituted by cuticle, epidermis, and hypodermis [61,62]; (b) the median mesocarp, formed by cells larger than those of the epidermis, mainly presenting a polygonal shape, thin cell walls, and large vacuoles; and (c) the inner endocarp, composed of crystal-containing cells where the seeds are found [63].

Leaves' texture and ultrastructure have great importance when choosing the most suitable varieties that can be used in food preparation. For instance, a V. vinifera variety whose leaves are rich in calcium oxalate crystals is not recommended for human consumption.

The $V$. vinifera leaf is a typical mesomorphic leaf [64], commonly large, alternate, petiolate with palmate lobes that may appear to be shaped like a hand. The color difference between the upper surface (dark green) and the lower surface (clear green) is evident and due fundamentally to the uneven distribution of chlorophyll pigments in the two layers, a greater quantity being present in the upper layer [62]. Although the structure of the vine leaf is different from cultivar to cultivar, it generally has a hand-like shape with three loops [65-67] (Figure 4). The leaf shows dorsoventrally anatomy with different parenchyma structure on the upper and lower page. It is surrounded by an outer protective tissue, the epidermis, with stomata fundamentally present in the lower epidermis surface. The mesophyll is heterogeneous and asymmetric due to the presence of a palisade parenchyma in the upper surface, characterized by rod-shaped cells with a lot of chloroplasts and a few intercellular air spaces, and a spongy parenchyma in the lower surface, characterized by isodiametric cells with an irregular contour and wide lacunas [68]. In the mesophyll, it is still possible to find a vascular 
system, composed of xylem (where water and minerals are transported) and phloem (where organic substances formed during photosynthesis are transported), and mechanical support tissues [62].

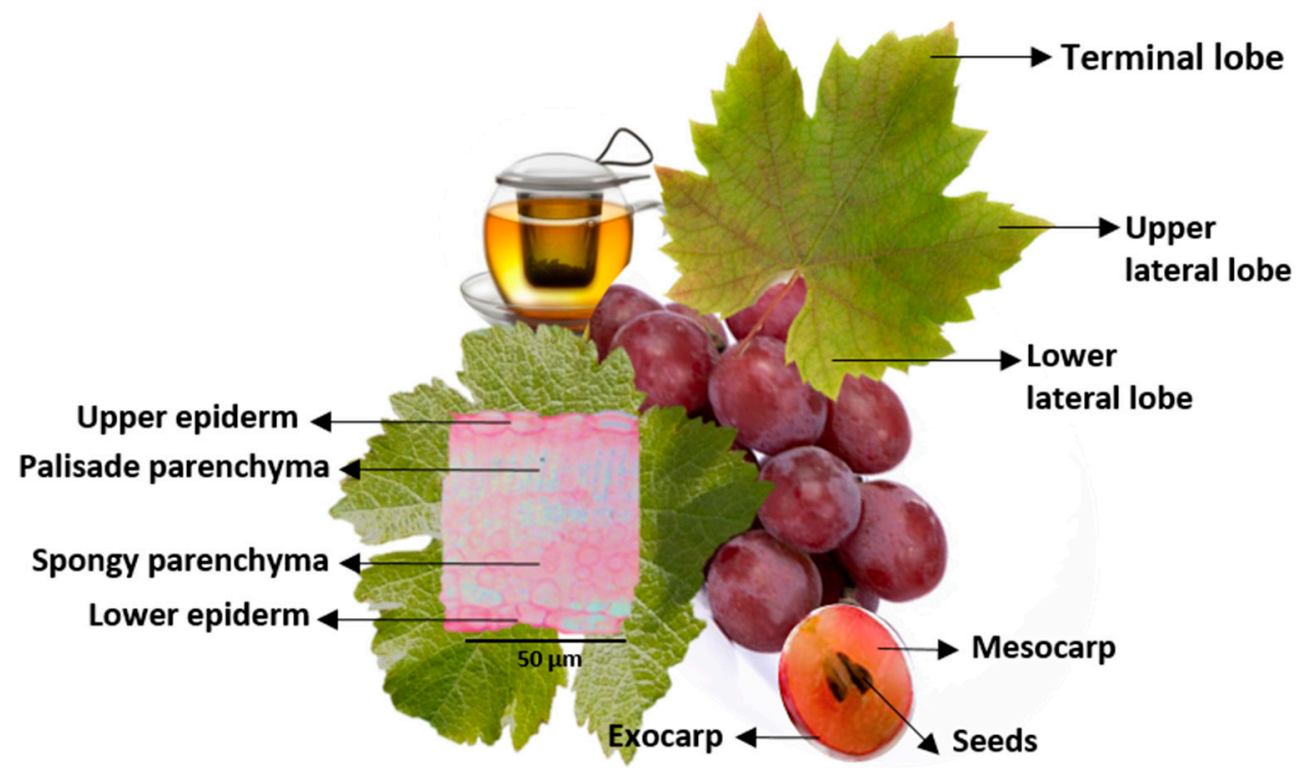

Figure 4. Schematic structures of a vine leaf and a grape berry.

\section{Infusions as a Valorization of Vineyards By-Products}

Wine production leads to the production of a vast number of by-products. The main ones are organic waste, such as grape pomace, seeds, pulp, skins, stems, and leaves, wastewater, greenhouse gases $\left(\mathrm{CO}_{2}\right)$ and other volatile organic compounds, and inorganic waste, such as diatomaceous earth, bentonite clay, and perlite [69].

Many of these by-products can be used as soil fertilizers and for the production of livestock feeds $[70,71]$. However, certain polyphenols present in winery by-products are phytotoxic and display antimicrobial effects during composting. Moreover, condensed tannins present in wine by-products can negatively affect animal digestibility. Hence, their valorization as a source of bioactive compounds for application in pharmaceutical, cosmetic, food, and beverage industries might constitute an efficient, profitable, and environment-friendly alternative for this kind of residues [72].

One application in the beverage sector is the use of dried non-fermented/semi-fermented and even fermented grapes, skins, and seeds (Figure 5) in the preparation of infusions or tisanes.
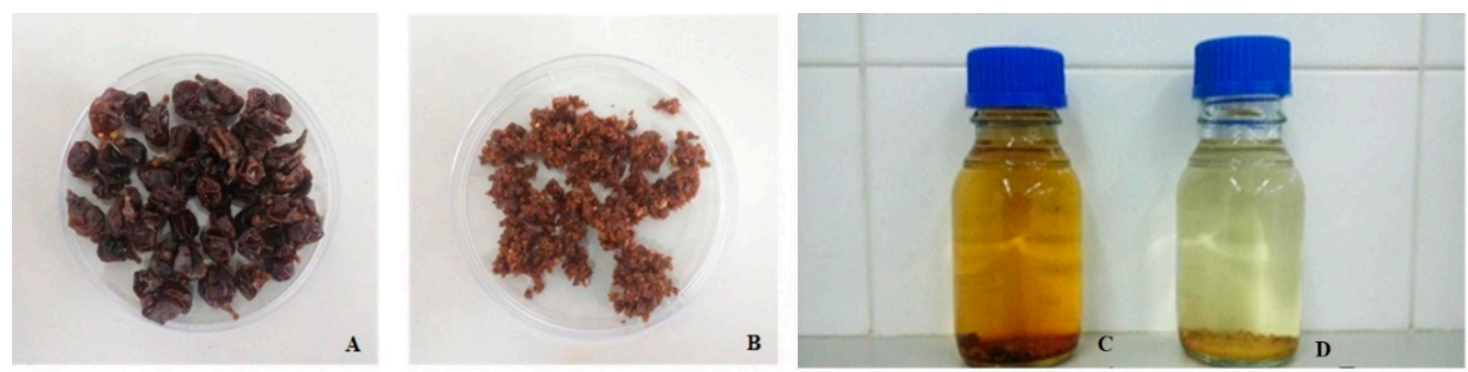

Figure 5. Dried (A) and triturated (B) non-fermented grapes, containing skins and seeds, of Moscatel Galego Portuguese grape variety; infusion prepared with grapes dried at $80^{\circ} \mathrm{C}(\mathrm{C})$ and $60{ }^{\circ} \mathrm{C}(\mathrm{D})$.

The non-fermented/semi-fermented or fermented grapes, skins, and seeds can be placed in trays and dried in an oven with controlled temperature and air circulation. The trays are weighed daily, at the same hour, and after achieving the minimum content in water [minimal difference of $0.5 \mathrm{~g}$ in weighing 
of the trays in two consecutive days, (Figure 5A)], the dry material (non-fermented/semi-fermented or fermented grapes, skins, and seeds) is crushed using a Moulinex kitchen robot mincer (Figure 5B).

The dried and minced material can then be used to prepare infusions. To this purpose, 6 to $3 \mathrm{~g} / \mathrm{L}$ of material, depending on the concentration wanted, are placed in a flask to which water is added at the temperature of about $100^{\circ} \mathrm{C}$ (Figure 5C,D).

The drying temperature of the grapes influences the infusion's chemical and sensory characteristics, including color (Figure 5C,D).

The use of grapes in the preparation of infusions or tisanes is particularly interesting when the grape chosen is from the Muscat family, with a pleasant aromatic fragrance, mainly due to its high content in terpenes alcohols [73]. According to the pioneer work of Ribéreau-Gayon and coworkers [73], the terpenic derivatives responsible for the aroma of Muscat grapes are mainly geraniol (the primary component of rose oil, palmarosa oil, and citronella oil), nerol (with a rose-like scent, widely used in perfumery), $\alpha$-terpineol (also found in natural oils such as pine oil and petitgrain), two furanic and two pyranic oxides of linalool (mild light floral odor with a slight citrus impression), Figure 6. Moreover, in the same work, it was reported that the total content of these compounds varies between $1 \mathrm{and} 3 \mathrm{mg} / \mathrm{L}$, with perception thresholds of 100 and more than $6000 \mu \mathrm{g} / \mathrm{L}$.

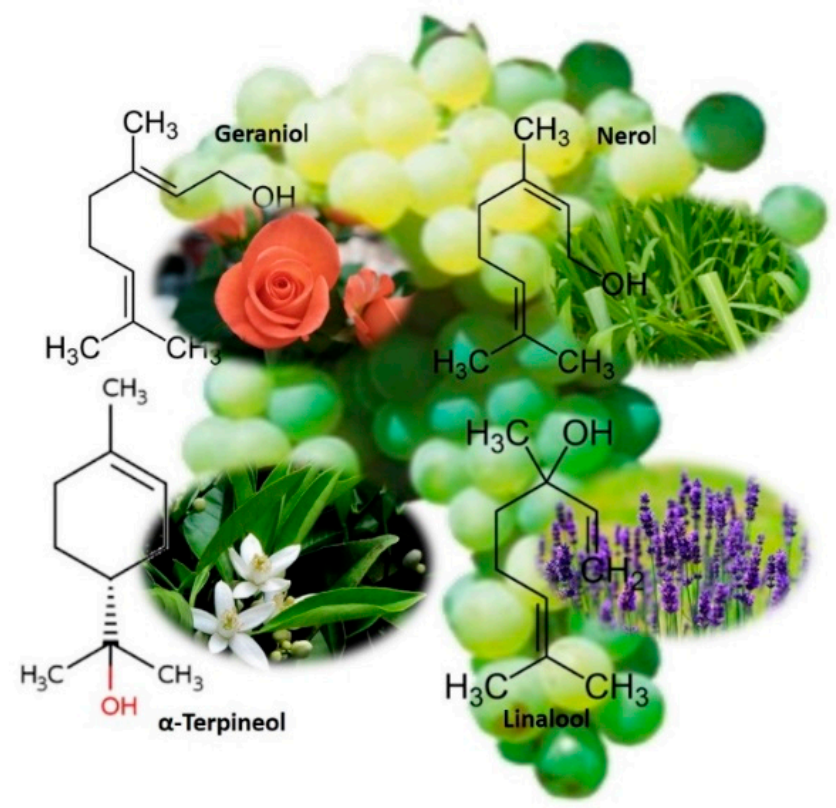

Figure 6. Set of the terpenic derivatives responsible for the aroma of Muscat grape varieties.

\section{Grape Infusions as an Alternative to Drug Treatment}

According to the definition of Kalra [39], the term "nutraceutical" is used to explain a food or parts of a food, which, in addition to its basic nutritional value, provides health benefits, including the prevention and treatment of diseases. So, nutraceuticals have been considered the link between nutrition and medicine. As described above, many herbal plants infusions are considered to have nutraceutical properties, due to their content of phenolic compounds. In the recent work of Gentile and coworkers [74], the authors concluded that antioxidant activity, content of phenolic compounds, and antiproliferative activity on cancer cells are nutraceutical properties.

One important nutraceutical property is the ability of a food or beverage to act as a free-radical scavenger, helping the human endogenous antioxidant system [75]. Metabolism causes oxidative stress on cells, resulting from an increasing concentration of reactive oxygen species (ROS) like $\mathrm{O}_{2}{ }^{\bullet-}$, $\mathrm{H}_{2} \mathrm{O}_{2}$, and $\mathrm{ROO}^{\bullet}$, that react with cellular constituents. To maintain a healthy biological system, it is important to balance the presence of ROS with antioxidants [76]. Polyphenols present in grapes, grape 
seeds, and grape skins have proven to possess this ability [75]. So, if these compounds exist in grape infusions, they will certainly present the same properties.

Presently, approximately 8000 different structures of plant phenolics are known [77]. Phenolic compounds can be differentiated in two groups: flavonoid and non-flavonoid compounds. The chemical structure of flavonoids is based on two aromatic rings connected by a bridge consisting of three carbons (C6-C3-C6). Flavonoids, usually in association with sugars, are divided into six main subclasses: flavonols, flavones, flavanones, flavan-3-ols, isoflavones, and anthocyanidins. The second group of plant phenolics, the non-flavonoids, can be subdivided into the following subgroups: phenolic acids (hydroxybenzoates, hydroxycinnamates), lignans, and stilbenes [78]. Tannins and lignins are two other subclasses of non-flavonoids. They are complex biopolymers and cannot be defined as primary carbon bases, since the chemical structure of a particular polyphenol is unique [79].

It is well known that the antioxidant activity of phenolic compounds is associated with: (i) the annular structure of the molecule; (ii) the conjugated double bonds; and (iii) the presence of functional groups in the ring. This antioxidant activity is carried out through several mechanisms such as inhibition of ROS formation, ROS trapping, and the extinction of molecular oxygen. Moreover, phenols can reduce the chelated metal ions that act as catalysts leading to the formation of ROS, interrupting the cascade of free radical reactions in lipid peroxidation and protecting the other compounds with antioxidant activity [80].

Besides the antioxidant activity, well-documented in various important works [81,82], polyphenols also possess anti-inflammatory properties [77]. During an inflammatory process, the enzyme phospholipase A2 (PLA2), which is stimulated by oxidative stress, leads to the release of arachidonic acid from the cell membrane phospholipids. The acid is then transformed by either the cyclooxygenase or the lipoxygenase pathway. Polyphenols inhibit both reactions, generally by blocking substrate binding to the enzyme through the interruption of the hydrogen bonding system or through chelation ions in the active site of the enzyme [80,83].

Moreover, phenolic compounds possess antiviral, antibacterial, and antifungal activity [84]. The antimicrobial activity has particular importance in the case of strains resistant to antibiotics, such as Staphylococcus aureus (resistant to methicillin), enterococci (resistant to glycopeptide antibiotics and vancomycin), pneumococci (resistant to $\beta$-lactam and macrolides), and Pseudomonas aeruginosa [84,85].

As it was mentioned above, grape infusions can be made with dried or lyophilized non-fermented grapes or skins and/or with dried or lyophilized semi-fermented or fermented grape skins and seeds. If in non-fermented grapes and grape sub-products such as grape skins, a huge number of nutraceutical compounds can be found, namely, polyphenols [86], in semi-fermented grape skins and seeds (from the fermentation of white wines) or fermented grape skins and seeds (from the fermentation of red wines) we can also find nutraceuticals provided by wine yeast metabolism $[87,88]$. That is the case of the amino acid tryptophan. This amino acid is the precursor of at least three biologically active compounds: melatonin, serotonin, and tryptophol [89].

Melatonin is a hormone produced by the pineal gland in your brain [90]. It is primarily responsible for regulating the body's circadian rhythm to manage the natural sleep cycle [91] and can be considered a sleep aid against insomnia; it is also involved in the control of immune function, blood pressure, and cortisol levels [92]. Serotonin is a neurotransmitter that contributes to well-being and happiness, among other things. As the precursor for melatonin, it helps regulate the body's sleep-wake cycles and the internal clock [89].

Rodriguez-Naranjo and co-workers [93] studied the properties of different yeasts. Moreover, the mechanisms mediating yeast resistance to stress may also induce the production of health-promoting compounds. This can be observed with dehydrated yeasts used by the wine-making industry. In the presence of hydric stress conditions, yeasts are able to synthesize compounds such as glutathione and trehalose $[94,95]$. Glutathione is an abundant low-molecular-weight thiol tripeptide containing glutamate, cysteine, and glycine (Glu-Cys-Gly). It can be found in reduced or oxidized forms (GSH and GSSG, respectively) and plays a crucial role in redox equilibrium reactions mediated via glutathione 
reductase and glutathione peroxidase $[95,96]$. Trehalose is a sugar found in many species of plants, animals, and microorganisms, including wine yeasts, where its function is to protect cells against desiccation. However, this sugar is not naturally present in mammals. Trehalose protects cellular membranes against denaturation as a result of desiccation and oxidative stress [97]. It can also be used as a pharmaceutical preventive drug to treat human eye dryness, a physiological condition that can lead to an inflammatory reaction [98].

During alcoholic fermentation, yeasts can produce tyrosol and tryptophol from the catabolism of the amino acids tyrosine and tryptophan, respectively, whereas hydroxytyrosol is produced by hydroxylation of tyrosol. These three compounds, derived from free-radical scavenging, are reported to possess several health-enhancing activities such as anticarcinogenic, cardioprotective [99], and antimicrobial properties [100].

Moreover, white wine has been reported to have cardioprotective benefits due to the presence of tyrosol and caffeic acids. Tyrosol and caffeic acids are able to activate cell survival signaling pathways and FOXO3a longevity-associated gene [101,102]. Tryptophol is also used in the treatment of benign prostatic hyperplasia and as a precursor in the synthesis of the drug Indoramin, used to treat hypertension $[103,104]$.

\section{Final Remarks}

Herbal infusions are the most popular form of herbal medicine in the world, having been used for thousands of years, and are even more ancient than tea. Their consumption is promoted by their medicinal properties due to their nutraceutical content. The chemical components of plants are of great interest, particularly with regard to health.

In the beverage sector, dried non-fermented/semi-fermented and fermented grapes, skins, and seeds are used in the preparation of infusions or tisanes. This is a way of valorizing grape/wine sub products, which are considered waste products after the process of fermentation during wine production.

The process to obtain "grape infusions" is easy, and its economic cost is mainly due to the electricity needed to dry the wet material. These infusions, besides being pleasant drinks, can provide health-promoting compounds which act as nutraceutical compounds.

In conclusion, herbal infusion/tisanes are, in general, an important vehicle for introducing health-promoting compounds into our diet, and those made with semi-fermented or fermented-grapes also allow a healthy environmental use of grape fermentation sub-products.

Acknowledgments: This research was funded by [CQ-VR, FCT-Portugal and COMPETE] grant number [PEst-OE/QUI/UI0616/2014] and by [CITAB, FCT-Portugal] grant number [UID/AGR/04033/2019]. Additional thanks to the IBERPHENOL project (Red Cooperativa de investigación en el ámbito de polifenoles y sus aplicaciones industriales).

Conflicts of Interest: The authors declare no conflict of interest.

\section{References}

1. Izzo, A.A.; Hoon-Kim, S.; Radhakrishnan, R.; Williamson, E.M. A critical approach to evaluating clinical efficacy, adverse events and drug interactions of herbal remedies. Phytother. Res. 2016, 30, 691-700. [CrossRef] [PubMed]

2. Taylor, S. Tea Types, Production, and Trade. In Encyclopedia of Food Science and Nutrition, 2nd ed.; Caballero, B., Finglas, P., Toldra, F., Eds.; Academic Press: Cambridge, MA, USA, 2003; pp. 5737-5743, ISBN 9780122270550.

3. Jäger, S.; Beffert, M.; Hoppe, K.; Nadberezny, D.; Frank, B.; Scheffler, A. Preparation of Herbal Tea as Infusion or by Maceration at Room Temperature Using Mistletoe Tea as an Example. Sci. Pharm. 2011, 79, 145-155. [CrossRef] [PubMed]

4. Guimarães, R.; Barros, L.; Carvalho, A.M.; Ferreira, I.C. Infusions and Decoctions of Mixed Herbs used in Folk Medicine: Synergism in Antioxidant Potential. Phytother. Res. 2011, 25, 1209-1214. [CrossRef] [PubMed] 
5. Malik, J.; Szakova, J.; Drabek, O.; Balik, J.; Kokoska, L. Determination of Certain Micro and Macroelements in Plant Stimulants and Their Infusions. Food Chem. 2008, 111, 520-525. [CrossRef] [PubMed]

6. Forest \& Kim Starr-Jardim Botânico UTAD. Available online: https://jb.utad.pt/fotografia/Camellia_sinensis. 2a244676b03172250ab320.pq.jpg (accessed on 5 May 2019).

7. Soni, R.P.; Katoch, M.; Kumar, A.; Ladohiya, R.; Verma, P. Tea: Production, Composition, Consumption and It's Potential as an Antioxidant and Antimicrobial Agent. Int. J. Food Ferment. Technol. 2015, 5, 95-106. [CrossRef]

8. Wang, C.; Lv, S.; Wu, Y.; Gao, X.; Li, J.; Zhang, W.; Meng, O. Oolong tea made from tea plants from different locations in Yunnan and Fujian, China showed similar aroma but different taste characteristics. SpringerPlus 2016, 5, 576. [CrossRef] [PubMed]

9. Sinija, V.R.; Mishra, H.N. Green tea: Health benefits, Review. J. Nutr. Environ. Med. 2008, 17, $232-242$. [CrossRef]

10. Lv, H.-P.; Dai, W.-D.; Tan, J.-F.; Guo, L.; Zhu, Y.; Lin, Z. Identification of the anthocyanins from the purple leaf colored tea cultivar Zijuan (Camellia sinensis var. assamica) and characterization of their antioxidant activities. J. Funct. Foods 2015, 17, 449-458. [CrossRef]

11. Lv, S.D.; Wu, Y.S.; Li, C.; Xu, Y.; Liu, L.; Meng, Q.X. Comparative analysis of Pu-erh and Fuzhuan teas by fully automatic headspace solid-phase microextraction coupled with gas chromatography-mass spectrometry and chemometric methods. J. Agric. Food Chem. 2014, 62, 1810-1818. [CrossRef]

12. Banerjee, R.; Bandyopadhyay, R.; Tudu, B.; Bhattacharyya, N. Tea and the Use of the Electronic Nose. In Electronic Noses and Tongues in Food Science; Méndez, M.L.R., Ed.; Academic Press: Cambridge, MA, USA, 2016; Chapter 13; pp. 125-135, ISBN 9780128002438. [CrossRef]

13. Yang, C.S.; Maliakal, P.; Meng, X. Inhibition of carcinogenesis by tea. Annu. Rev. Pharmacol. Toxicol. 2002, 42, 25-54. [CrossRef]

14. Pou, K.R.J. Fermentation: The Key Step in the Processing of Black Tea. J. Biosyst. Eng. 2016, 41, 85-92. [CrossRef]

15. Samanta, T.; Cheeni, V.; Das, S.; Roy, A.B.; Ghosh, B.C.; Mitra, A. Assessing biochemical changes during the standardization of fermentation time and temperature for manufacturing quality black tea. J. Food Sci. Technol. 2015, 52, 2387-2393. [CrossRef] [PubMed]

16. Carloni, P.; Tiano, L.; Padella, L.; Bacchetti, T.; Customu, C.; Kay, A.; Damiani, E. Antioxidant activity of white, green and black tea obtained from the same tea cultivar. Food Res. Int. 2013, 53, 900-908. [CrossRef]

17. Middleton, E.; Kandaswami, C.; Theoharis, T.C. The effects of plant flavonoids on mammalian cells: Implications for inflammation, heart disease, and cancer. Pharmacol. Rev. 2000, 52, 673-751. [PubMed]

18. Balasundram, N.; Sundram, K.; Samman, S. Phenolic compounds in plants and agri-industrial by-products: Antioxidant activity, occurrence, and potential uses. Food Chem. 2006, 99, 191-203. [CrossRef]

19. Herrera, T.; Aguilera, Y.; Rebollo-Hernanza, M.; Bravoa, E.; Beníteza, V.; Martínez-Sáezb, N.; Arribasc, S.M.; Castillo, M.D.; Martín-Cabrejasa, M.A. Teas and herbal infusions as sources of melatonin and other bioactive non-nutrient components. LWT 2018, 89, 65-73. [CrossRef]

20. Lee, J.; Chambers, D.H. A lexicon for flavor descriptive analysis of green tea. J. Sens. Stud. 2007, 22, $256-272$. [CrossRef]

21. Khokhar, S.; Magnusdottir, S.G.M. Total phenol, catechin, and caffeine contents of teas commonly consumed in the United Kingdom. J. Agric. Food Chem. 2002, 50, 565-570. [CrossRef]

22. Byun, J.-O.; Han, J.-S. A study perception and actual status of utilization for green tea. J. Korean Soc. Food Cult. 2004, 19, 184-192.

23. Dhalla, N.S.; Temsah, R.M.; Netticadan, T. Role of oxidative stress in cardiovascular diseases. J. Hypertens. 2000, 18, 655-673. [CrossRef]

24. Leung, L.K.; Su, Y.; Chen, R.; Zhang, Z.; Huang, Y.; Chen, Z.-U. Theaflavins in Black Tea and Catechins in Green Tea Are Equally Effective Antioxidants. J. Nutr. 2001, 131, 2248-2251. [CrossRef] [PubMed]

25. Rice-Evans, C. Implications of the mechanisms of action of tea polyphenols as antioxidants in vitro for chemoprevention in humans. Proc. Soc. Exp. Biol. Med. 1999, 220, 262-266. [CrossRef] [PubMed]

26. Atoui, A.K.; Mansouri, A.; Boskou, G.; Kefalas, P. Tea, and herbal infusions: Their antioxidant activity and phenolic profile. Food Chem. 2005, 89, 27-36. [CrossRef] 
27. Yoshino, K.; Hara, Y.; Sano, M.; Tomita, S. Antioxidative effects of black tea theaflavins and thearubigin on lipid peroxidation of rat liver homogenates induced by tert-butyl hydroperoxide. Biol. Pharm. Bull. 1994, 17, 146-149. [CrossRef] [PubMed]

28. Borghi, L.; Meschi, T.; Schianchi, T.; Briganti, A.; Guerra, A.; Allegri, F.; Novarini, A. Urine volume: Stone risk factor and preventive measure. Nephron 1999, 81 (Suppl. 1), 31-37. [CrossRef] [PubMed]

29. Simpson, A.; Shaw, L.; Smith, A.J. The bio-availability of Fluoride from black tea. J. Dent. Oral Biol. 2001, 29, 15-21. [CrossRef]

30. Hegarty, V.M.; May, H.M.; Khaw, K.T. Tea drinking and bone mineral density in older women. Am. J. Clin. Nutr. 2000, 71, 1003-1007. [CrossRef]

31. Pascual, M.E.; Slowing, K.; Carretero, E.; Sánchez, D.M.; Villar, A. Lippia: Traditional Uses, Chemistry, and Pharmacology: A Review. J. Ethnopharmacol. 2001, 76, 201-214. [CrossRef]

32. Kerharo, M.; Adam, A. La Pharmacopée Sénégalaise Traditionnelle—Plantes Médicinales Et Toxiques; Vigot: Paris, France, 1974; 778p, ISBN 2-7114-0646-6.

33. Ouedraogo, O.G. Plantes Médicinales et Pratiques Médicales Traditionnelles du Burkina Faso: Cas du Plateau Central. Thèse de l'Université de Ouagadougou, Université de Ouagadougou, Ouagadougou, Burkina Faso, 1986; 261p.

34. Abena, A.A.; Diatewa, M.; Gakossi, G.; Gbeassor, M.; Hondi-Assah, T.H.; Ouamba, J.M. Analgesic, Antipyretic and Anti-Inflammatory Effects of Essential oil of Lippia multiflora. Fitoterapia 2003, 74, 231-236. [CrossRef]

35. Massey, L.K. Dietary Influences on Urinary Oxalate and Risk of Kidney Stones. Front. Biosci. 2003, 8, s584-s594. [CrossRef]

36. Daliu, P.; Santini, A.; Novellino, E. A decade of nutraceutical patents: Where are we now in 2018? Expert Opin. Ther. Pat. 2018, 28, 875-882. [CrossRef] [PubMed]

37. Witkamp, R.F.; Norren, K. Let thy food be thy medicine ... .when possible. Eur. J. Pharmacol. 2018, 836, 102-114. [CrossRef] [PubMed]

38. Anjo, D.L.C. Alimentos funcionais em angiologia e cirurgia vascular. J. Vasc. Bras. 2004, 3, 145-154.

39. Kalra, E.K. Nutraceutical definition and introduction. AAPS PharmSci 2003, 5, 27-28. [CrossRef] [PubMed]

40. Santini, A.; Cammarata, S.M.; Capone, A.; Ianaro, A.; Tenore, G.C.; Pani, L.; Novellino, E. Nutraceuticals: Opening the debate for a regulatory framework. Br. J. Clin. Pharmacol. 2018, 84, 659-672. [CrossRef] [PubMed]

41. Fernandes, A.M.J. Investigação Clínica Com Nutracêuticos. Mater's Thesis, Coimbra University, Coimbra, Portugal, 2016.

42. Dudeja, P.; Gupta, R.K. Tea and the Use of the Electronic Nose. In Food Safety in the 21st Century, Public Health Perspective; Gupta, R.K., Dudeja, S., Minhas, S., Eds.; Academic Press: Cambridge, MA, USA, 2017; Chapter 40; pp. 125-135, ISBN 978-0-12-801773-9. [CrossRef]

43. Andlauer, W.; Furts, P. Nutraceuticals: A piece of history, present status, and Outlook. Food Res. Int. 2002, 35, 171-176. [CrossRef]

44. Bircher, J.; Hahn, E.G. Understanding the nature of health: New perspectives for medicine and public health. Improved wellbeing at lower costs. F1000Research 2016, 5, 167. [CrossRef]

45. Durazzo, A.; D'Addezio, L.; Camilli, E.; Piccinelli, R.; Turrini, A.; Marletta, L.; Marconi, S.; Lucarini, M.; Lisciani, S.; Gabrielli, P.; et al. From Plant Compounds to Botanicals and Back: A Current Snapshot. Molecules 2018, 23, 1844. [CrossRef]

46. Télessy, I.G. Nutraceuticals. In The Role of Functional Food Security in Global Health; Singh, R.B., Watson, R., Takahashi, T., Eds.; Academic Press: Cambridge, MA, USA, 2019; Chapter 24; pp. 409-421, ISBN 978-0-12-813148-0. [CrossRef]

47. Magalhães, N. Tratado de Viticultura: A Videira, a Vinha e o "Terroir"; Esfera, P., Ed.; Chaves Ferreira: Lisboa, Portugal, 2008; 605p. ISBN 9789899820739.

48. Dani, C.; Oliboni, L.S.; Agostini, F.; Funchal, C.; Serafini, L.; Henriques, J.A.; Salvador, M. Phenolic content of grapevine leaves (Vitis labrusca var. Bordo) and its neuroprotective effect against peroxide damage. Toxicol. In Vitro 2010, 24, 148-153. [CrossRef]

49. Orhan, D.D.; Orhan, N.; Ergun, F. Hepatoprotective effect of Vitis vinifera L. leaves on carbon tetrachloride-induced acute liver damage in rats. J. Ethnopharmacol. 2007, 12, 145-151. [CrossRef]

50. Cosme, F.; Pinto, T.; Vilela, A. Oenology in the Kitchen: The Sensory Experience Offered by Culinary Dishes Cooked with Alcoholic Drinks, Grapes and Grape Leaves. Beverages 2017, 3, 42. [CrossRef] 
51. Harb, J.; Alseekh, S.; Tohge, T.; Fernie, A.R. Profiling of primary metabolites and flavonols in leaves of two table grape varieties collected from semiarid and temperate regions. Phytochemistry 2015, 117, 444-455. [CrossRef]

52. Pastrana-Bonilla, E.; Akoh, C.C.; Sellappan, S.; Krewer, G. Phenolic content and antioxidant capacity of muscadine grapes. J. Agric. Food Chem. 2003, 51, 5497-5503. [CrossRef]

53. Prieur, C.; Rigaud, J.; Cheynier, V.; Moutounet, M. Oligomeric and polymeric procyanidins from grape seeds. Phytochemistry 1994, 3, 781-784. [CrossRef]

54. Fuleki, T.; Ricardo-Da-Silva, J.M. Effects of cultivar and processing method on the contents of catechins and procyanidins in grape juice. J. Agric. Food Chem. 2003, 51, 640-646. [CrossRef]

55. Peynaud, E.; Ribéreau-Gayon, P. The grape. In The Biochemistry of Fruits and Their Products; Hulme, A.C., Ed.; Academic: London, UK, 1971; Volume 2, Chapter 4.

56. Katalinic, V.; Generalic, I.; Skroza, D.; Ljubenkov, I.; Teskera, A.; Konta, I.; Boban, M. Insight in the phenolic composition and antioxidative properties of Vitis vinifera leaves extracts. Croat. J. Food Sci. Technol. 2009, 1, 7-15.

57. Lacerda, D.S.; Costa, P.C.; Funchal, C.; Dani, C.; Gomez, R. Benefits of Vine Leaf on Different Biological Systems. In Grape and Wine Biotechnology; IntechOpen: London, UK, 2016; pp. 125-143. [CrossRef]

58. Radovanović, B.; Andjelković, M.; Radovanović, V.; Milenković-Andjelković, A.; Snežana Đekić, S. Polyphenols and Antioxidant Activity of Different Vinegrape Leaves. Zb. Rad. 2015, 20, 347-352.

59. Balik, J.; Kyseláková, M.; Vrchotová, N.; Triska, J.; Kumsta, M.; Veverka, J.; HÍc, P.; Totusek, J.; Lefnerová, D. Relations between polyphenols content and antioxidant activity in vine grapes and leaves. Czech J. Food Sci. 2008, 26, S25-S32. [CrossRef]

60. Sat, I.G.; Sengul, M.; Keles, F. Use of Grape Leaves in Canned Food. Pak. J. Nutr. 2002, 1, 257-262.

61. Ribéreau-Gayon, P.; Dubourdieu, D.; Donèche, B.; Lonvaud, A. The Microbiology of Wine and Vinifications. In Handbook of Enology, 1st ed.; Wiley: Chichester, UK, 2000; Volume 1.

62. Cosme, F.; Pinto, T.; Vilela, A. Phenolic Compounds and Antioxidant Activity in Grape Juices: A Chemical and Sensory View. Beverages 2018, 4, 22. [CrossRef]

63. Hardie, W.J.; O’Brien, T.P.; Jaudzems, V.G. Morphology, anatomy and development of the pericarp after anthesis in grape, Vitis vinifera L. Aust. J. Grape Wine Res. 1996, 2, 97-142. [CrossRef]

64. Karabourniotis, G.; Bornman, J.F.; Nikolopoulos, D. A possible optical role of the bundle sheath extensions of the heterobaric leaves of Vitis vinifera and Quercus coccifera. Plant Cell Environ. 2000, 23, 423-430. [CrossRef]

65. Boso, S.; Gago, P.; Alonso-Villaverde, V.; Santiago, J.J.; Mendez, J.; Pazos, I.; Martínez, M.C. Variability at the electron microscopy level in leaves of members of the genus Vitis. Sci. Hortic. 2011, 128, 228-238. [CrossRef]

66. Koundouras, S.; Tsialtas, I.T.; Zioziou, E.; Nikolaou, N. Rootstock effects on the adaptive strategies of grapevine (Vitis vinifera L. cv. Cabernet-Sauvignon) under contrasting water status: Leaf physiological and structural responses. Agric. Ecosyst. Environ. 2008, 128, 86-96. [CrossRef]

67. Monteiro, A.; Teixeira, G.; Lopes, C.M. Comparative leaf micromorphoanatomy of Vitis vinifera ssp. vinífera (Vitaceae) red cultivars. Ciênc. Téc. Vitivinic. 2013, 28, 19-28.

68. Pinto, T.M.; Anjos, M.D.R.; Martins, N.M.; Gomes-Laranjo, J.; Ferreira-Cardoso, J.; Peixoto, F. Structural analysis of Castanea sativa Mill. leaves from different regions in the tree top. Braz. Arch. Biol. Technol. 2011, 54, 117-124. [CrossRef]

69. Oliveira, D.A.; Salvador, A.A.A.S.; Smânia, E.F.A.; Maraschin, M.; Ferreira, S.R.S. Antimicrobial activity and composition profile of grape (Vitis vinifera) pomace extracts obtained by supercritical fluids. J. Biotechnol. 2013, 164, 423-432. [CrossRef]

70. Arvanitoyannis, I.S.; Ladas, D.; Mavromatis, A. Potential uses and applications of treated wine waste. Int. J. Food Sci. Technol. 2006, 41, 475-487. [CrossRef]

71. Harsha, P.S.C.S.; Gardana, C.; Simonetti, P.; Spigno, G.; Lavelli, V. Characterization of phenolics, in vitro reducing capacity and anti-glycation activity of red grape skins recovered from winemaking by-products. Bioresour. Technol. 2013, 140, 263-268. [CrossRef]

72. Makris, D.P.; Boskou, G.; Andrikopoulos, N.K. Polyphenolic content and in vitro antioxidant characteristics of the wine industry and other Agri-food solid waste extracts. J. Food Comp. Anal. 2007, 20, 125-132. [CrossRef]

73. Ribéreau-Gayon, P.; Boidron, J.N.; Terrier, A. Aroma of Muscat Grape Varieties. J. Agric. Food Chem. 1975, 23. [CrossRef] 
74. Gentile, C.; Reig, C.; Corona, O.; Farina, V.; Todaro, A.; Mazzaglia, A.; Perrone, A.; Gianguzzi, G.; Agusti, M. Pomological traits, sensory profile and nutraceutical properties of nine cultivars of loquat (Eriobotrya japonica Lindl.) fruits grown in Mediterranean area. Plant Foods Hum. Nutr. 2016, 71, 330-338. [CrossRef]

75. Katalinic, V.; Milos, M.; Kulisic, T.; Jukic, M. Screening of 70 medicinal plant extracts for antioxidant capacity and total phenols. Food Chem. 2006, 94, 550-557. [CrossRef]

76. Valko, M.; Leibfritz, D.; Moncol, J.; Cronin, M.T.; Mazur, M.; Telser, J. Free radicals and antioxidants in normal physiological functions and human disease. Int. J. Biochem. Cell Biol. 2007, 39, 44-84. [CrossRef]

77. Działo, M.; Mierziak, J.; Korzun, U.; Preisner, M.; Szopa, J.; Kulma, A. The Potential of Plant Phenolics in Prevention and Therapy of Skin Disorders. Int. J. Mol. Sci. 2016, 17, 160. [CrossRef]

78. Del Rio, D.; Rodriguez-Mateos, A.; Spencer, J.P.; Tognolini, M.; Borges, G.; Crozier, A. Dietary (poly)phenolics in human health: Structures, bioavailability, and evidence of protective effects against chronic diseases. Antioxid. Redox Signal. 2013, 18, 1818-1892. [CrossRef]

79. Le Floch, A.; Jourdes, M.; Teissedre, P.L. Polysaccharides and lignin from oak wood used in cooperage: Composition, interest, assays: A review. Carbohydr. Res. 2015, 417, 94-102. [CrossRef]

80. Samoylenko, A.; Hossain, J.A.; Mennerich, D.; Kellokumpu, S.; Hiltunen, J.K.; Kietzmann, T. Nutritional countermeasures targeting reactive oxygen species in cancer: From mechanisms to biomarkers and clinical evidence. Antioxid. Redox Signal. 2013, 19, 2157-2196. [CrossRef]

81. Yoo, H.G.; Lee, B.H.; Kim, W.; Lee, J.S.; Kim, G.H.; Chun, O.K.; Koo, S.I.; Kim, D.O. Lithospermum erythrorhizon extract protects keratinocytes and fibroblasts against oxidative stress. J. Med. Food. 2014, 17, 1189-1196. [CrossRef]

82. Alov, P.; Tsakovska, I.; Pajeva, I. Computational studies of free radical-scavenging properties of phenolic compounds. Curr. Top. Med. Chem. 2015, 15, 85-104. [CrossRef]

83. Arct, J.; Bielenda, B.; Oborska, A.; Pytkowska, K. The tea and its cosmetic application. J. Appl. Cosmetol. 2003, 21, 117-127.

84. Czemplik, M.; Zuk, M.; Kulma, A.; Kuc, S.; Szopa, J. GM flax as a source of effective antimicrobial compounds. Sci. Microb. Pathog. Commun. Curr. Res. Technol. Adv. 2011, 76, 39-47.

85. Anani, K.; Adjrah, Y.; Ameyapoh, Y.; Karou, S.D.; Agbonon, A.; de Souza, C.; Gbeassor, M. Effects of hydroethanolic extracts of Balanites aegyptiaca (L.) Delile (Balanitaceae) on some resistant pathogens bacteria isolated from wounds. J. Ethnopharmacol. 2015, 164, 16-21. [CrossRef]

86. Ozcan, T.; Akpinar-Bayizit, A.; Yilmaz-Ersan, L.; Delikanli, B. Phenolics in Human Health. Int. J. Chem. Eng. Appl. 2014, 5, 393-396. [CrossRef]

87. Guerrini, S.; Mangani, S.; Romboli, Y.; Luti, S.; Pazzagli, L.; Granchi, L. Impact of Saccharomyces cerevisiae Strains on Health-Promoting Compounds in Wine. Fermentation 2018, 4, 26. [CrossRef]

88. Vilela, A. The Importance of Yeasts on Fermentation Quality and Human Health-Promoting Compounds. Fermentation 2019, 5, 46. [CrossRef]

89. Mas, A.; Guillamon, J.M.; Torija, M.J.; Beltran, G.; Cerezo, A.B.; Troncoso, A.M.; Garcia-Parrilla, M.C. Bioactive compounds derived from the yeast metabolism of aromatic amino acids during alcoholic fermentation. BioMed Res. Int. 2014, 2014. [CrossRef]

90. Liu, J.; Huang, F.; He, H.W. Melatonin effects on hard tissues: Bone and tooth. Int. J. Mol. Sci. 2013, 14, 10063-10074. [CrossRef]

91. Masters, A.; Pandi-Perumal, S.R.; Seixas, A.; Girardin, J.L.; McFarlane, S.I. Melatonin, the Hormone of Darkness: From Sleep Promotion to Ebola Treatment. Brain Disord. Ther. 2014, 4. [CrossRef]

92. Claustrat, B.; Leston, L. Melatonin: Physiological effects in humans. Neurochirurgie 2015, 61, 77-84. [CrossRef]

93. Rodriguez-Naranjo, M.I.; Gil-Izquierdo, A.; Troncoso, A.M.; Cantos, E.C.; Garcia-Parrilla, M.C. Melatonin: A new bioactive compound present in wine. J. Food Comp. Anal. 2011, 24, 603-608. [CrossRef]

94. Câmara, A.A., Jr.; Nguyen, T.D.; Jossier, A.; Endrizzi, A.; Saurel, R.; Simonin, H.; Husson, F. Improving total glutathione and trehalose contents in Saccharomyces cerevisiae cells to enhance their resistance to fluidized bed drying. Process Biochem. 2018, 69, 45-51. [CrossRef]

95. Chakravarthi, S.; Jessop, C.E.; Bulleid, N.J. The role of glutathione in disulfide bond formation and endoplasmic-reticulum-generated oxidative stress. EMBO Rep. 2006, 7, 271-275. [CrossRef]

96. Rahman, I.; Kode, A.; Biswas, S.K. Assay for quantitative determination of glutathione and glutathione disulfide levels using enzymatic recycling method. Nat. Protoc. 2007, 1, 3159. [CrossRef] 
97. Eleutherio, E.; Panek, A.; De Mesquita, J.F.; Trevisol, E.; Magalhães, R. Revisiting yeast trehalose metabolism. Curr. Genet. 2015, 61, 263-274. [CrossRef]

98. Luyckx, J.; Baudouin, C. Trehalose: An intriguing disaccharide with potential for medical application in ophthalmology. Clin. Ophthalmol. 2011, 5, 577-581. [CrossRef]

99. Samuel, S.M.; Thirunavukkarasu, M.; Penumathsa, S.V.; Paul, D.; Maulik, N. Akt/FOXO3a/SIRT1-Mediated Cardioprotection by $n$-Tyrosolagainst Ischemic Stress in Rat In Vivo Model of Myocardial Infarction: Switching Gears toward Survival and Longevity. J. Agric. Food Chem. 2008, 56, 9692-9698. [CrossRef]

100. Dudley, J.I.; Lekli, I.; Mukherjee, S.; Das, M.; Bertelli, A.A.; Das, D.K. Does white wine qualify for French paradox? Comparison of the cardioprotective effects of red and white wines and their constituents: Resveratrol, tyrosol, and hydroxytyrosol. J. Agric. Food Chem. 2008, 56, 9362-9373. [CrossRef]

101. Willcox, B.J.; Donlon, T.A.; He, Q.; Chen, R.; Grove, J.S.; Yano, K.; Masaki, K.H.; Willcox, D.C.; Rodriguez, B.; Curb, J.D. FOXO3a Genotype Is Strongly Associated with Human Longevity. Proc. Natl. Acad. Sci. USA 2008, 105, 13987-13992. [CrossRef]

102. Thirunavukkarasu, M.; Penumathsa, S.V.; Samuel, S.M.; Akita, Y.; Zhan, L.; Bertelli, A.A.; Maulik, G.; Maulik, N. White Wine-Induced Cardio Protection against Ischemia-Reperfusion Injury is Mediated by Life-Extending Akt/FOXO3a/NFkB Survival Pathway. J. Agric. Food Chem. 2008, 56, 6733-6739. [CrossRef]

103. Kirby, R.S.; Pool, J.L. Alpha adrenoceptor blockade in the treatment of benign prostatic hyperplasia: Past, present, and future. Br. J. Urol. 1997, 80, 521-532. [CrossRef]

104. Gould, B.A.; Mann, S.; Davies, A.B.; Altman, D.G.; Raftery, E.B. $\alpha$-Adrenoreceptor Blockade with Indoramin in Hypertension. J. Cardiovasc. Pharmacol. 1983, 5, 343-348. [CrossRef]

(C) 2019 by the authors. Licensee MDPI, Basel, Switzerland. This article is an open access article distributed under the terms and conditions of the Creative Commons Attribution (CC BY) license (http://creativecommons.org/licenses/by/4.0/). 